\section{ISONOMIA: UM BREVE ENSAIO ACERCA DA TEORIA VALORATIVA E DE SUA BUSCA PELA IGUALDADE SUBSTANCIAL*}

\author{
ISONOMÍA: UN BREVE ENSAYO SOBRE LA \\ TEORÍA VALORATIVA Y SU BÚSQUEDA DE LA \\ IGUALDAD SUBSTANTIVA
}

\author{
ISONOMY: A BRIEF ESSAY ON VALUATION \\ THEORY AND ITS RESEARCH OF \\ SUBSTANTIAL EQUALITY
}

\title{
RESUMO
}

0 direito à igualdade pugna pelo tratamento justo por intermédio de um regulador de diferenças. Veda-se, nessa vertente, o emprego arbitrário de tratamentos iguais para aqueles que se encontram em situações manifestamente desiguais ou, ainda, diferenciações destituídas de justificação razoável, baseadas em critérios discriminatórios, preconeituosos ou injustificáveis. Proíbe-se a discriminação e fomenta-se a insurgência do Poder Público para compensar as desigualdades de natureza social, cultural e econômica. Há muito a ser feito para que galguemos a almejada igualdade concreta.

\footnotetext{
* O presente artigo traduz um estudo realizado para o Instituto Brasileiro de Direitos Humanos (IBDH), no ano de 2014. Isso porque, mesmo com a evolução das Constituições no sentido de se buscar uma igualdade substancial, é visível em diversas partes do mundo atitudes de discriminações raciais similares àquelas havidas nos períodos mais funestos para os direitos fundamentais (justificativa da pesquisa). Nesse cipoal, sob o enfoque do direito à igualdade, exsurge a indagação acerca de qual o melhor instrumento (ou mecanismo) para se debelar denotado comportamento e, pari passu, galgar uma igualdade concreta entre todos os indivíduos (problema de pesquisa). É este, diga-se de passagem, o propósito deste trabalho - realizado por intermédio de um método dedutivo, com procedimento histórico-comparativo e estudo de bibliografias acerca do tema (metodologia).

a. Advogado. Presidente da Comissão de Cultura da 18a Subseção da Ordem dos Advogados do Brasil - São Paulo (2013/2015). Professor no Departamento de Ciências Jurídicas da Universidade de Taubaté. Especialista em Direito Processual Civil, Ciências Penais, Direito Público e Direito Constitucional. Membro do Instituto Brasileiro de Direito Processual Penal (IBRASPP); do Instituto Brasileiro de Direitos Humanos (IBDH) e do "International Center of Economic Penal Studies" (ICEPS - New York).
}

Fernando Gentil Gizzi de Almeida a fgizzi@uol.com.br Fecha de recepción: 18 de febrero de 2015 Fecha de revisión: 1 de marzo de 2015 Fecha de aceptación: 26 de abril de 2015
MISIÓN JURÍDICA

Revista de Derecho y Ciencias Sociales Bogotá, D.C. (Colombia) Colaboradores Externos Internacionales Núm. 9, Año 2015

Junio - Diciembre, pp. 49 - 67

ISSN 1794-600X 


\section{PALAVRAS-CHAVE}

Direito à igualdade; não discriminação; Teoria Valorativa.

\section{RESUMEN}

El derecho a la igualdad se esfuerza por lograr un trato justo por medio de la regulación de las diferencias. En tal escenario, se prohíbe el uso arbitrario de la igualdad de trato a quienes están en una situación claramente desigual o, aún, distinción de trato sin justificación razonable, basada en criterios discriminatorios, por preconcepto o injustificables. La discriminación está prohibida, y la insurgencia del Poder Público se fomenta con el fin de compensar las desigualdades sociales, culturales y económicas. Todavía hay mucho por hacer antes de alcanzar la tan anhelada igualdad real.

\section{PALABRAS CLAVE}

Derecho a la Igualdad, No Discriminación, Teoría de Valoración

\begin{abstract}
The right to equality makes an effort to achieve a fair manner by the regulation of the differences. In such scenario it is forbidden the arbitrary use of equality of manner with whom are in a clearly unequal situation or are being treated differently without a reasonable justification, based on discriminatory judgement: unjustifiable or by preconception. The discrimination is prohibited and the uprising of the Public Power is fomented with the purpose of compensating social, cutlural and economic unequalities. There is still ,much to do before reaching the so much desired real equality.
\end{abstract}

\section{KEY WORDS}

Right to equality, non-discirmination, valuation theory.

\section{PROPEDÊUTICA}

\subsection{Gênese axiológica}

Consoante o perpassar da história, é possível pontuar que, desde as primevas eras, o direito fundamental à igualdade se fez presente
- ainda que, timidamente, servindo: a) de lastro para o fomento das religiões; b) como pedra de toque para a Democracia Direta dos Gregos (Século de Péricles, entre VI e IV a.C) ${ }^{1}$ ou; ademais, c) como estofo para o exsurgir da Magna Charta Libertatum ${ }^{2}$, outorgada por João sem Terra, que trazia em seu bojo a afirmação de que nenhum homem (inclusive o rei) estaria acima da ordem legal.

Entrementes, é digno de nota que tão só no período das revoluções Liberais, em especial com a Revolução Francesa (1789-1799), que tal direito atingiu outro patamar.

Não por outra razão, nos debruçamos sobre aquele momento histórico, muito bem retratado na obra Les Misérables (Victor Hugo) - que, de certa forma, exterioriza a realidade vivenciada, de maneira um pouco antecedente, pelo Padre francês Emmanuel Joseph Sieyès -, onde o alto clero $\left(1^{\circ}\right.$ Estado) e a nobreza $\left(2^{\circ}\right.$ Estado) participavam das deliberações políticas, que decidiam o norte do destino de toda nação, sem a participação da Burguesia-Povo ( $3^{\circ}$ Estado), a quem sopesava uma alta incidência tributária.

Daí, a razão da Constituinte Burguesa ("0 que é o Terceiro Estado? / Qu'est-ce que le tier état?) que, escrita pelo próprio abade Sieyès, com estofo no supreme power de John Locke (Dois Tratrados sobre o Governo) e no Contrato Social de JeanJacques Rousseau, proclamava a insurreição da Burguesia-Povo ( $3^{\circ}$ Estado) para as decisões políticas que diziam respeito a sua própria sina.

Nesse passo, o direito à igualdade, já existente nos Estados Unidos da América (Declaração dos Direitos da Virgínia, de 1776), não tardou a aflorar.

No borbulhar da crise fiscal, somada a insatisfação emergente dos franceses com o rei

1. Que, num movimento político-jurídico de estabelecer governos moderados e limitados em seus poderes (Constitucionalismo Antigo), tornou o Estado eletivo e subordinado à Assembleia dos Cidadãos. (FERREIRA FILHO, Manoel Gonçalves. Curso de direito constitucional. 12ª ed. São Paulo: Editora Saraiva, 1993. p.7)

2. 15 de junho de 1215. Tal documento, diga-se en passant, trouxe à baila o denominado Rule of Law-gênese do due process of law (devido processo legal) -, que substituiu o pretérito governo dos homens e serviu de inspiração para diversos documentos jurídicos de relevância, como a Petition of Rights (1628); Habeas Corpus Act (1679); Bill of Rights (1689); Act of Settlement (1701) e outros. 
Luís XVI (guilhotinado em 1793), a população ( $3^{\circ}$ Estado), já inflamada com os ideais iluministas e com a obra de Sieyès, tomou a Bastilha ${ }^{3}$ e perpetrou a Déclaration des Droits de l'Homme et du citoyen (Declaração dos Direitos do Homem e do Cidadão ${ }^{4}$ ), onde se trouxe a premissa de que "os homens nascem e são livres e iguais em direitos ${ }^{5 "}$

Exsurgiu, deste modo, a chamada Teoria Paritária do direito à isonomia (igualdade formal). Id est, nasce o elucubrar de que todos os homens são iguais perante a lei $^{6}$ - que foi mecanismo encontrado como forma de se contrapor ao absolutismo, até então, reinante.

Vale dizer! Com estofo no art. $6^{\circ}$ da Declaração - "a lei é expressão da vontade geral (...). Ela deve ser a mesma para todos, seja para proteger, seja para punir" -, passou-se a ter uma igualdade absoluta em termos jurídicos. Houve o debelar de uma sociedade pautada em privilégios hereditários e estamentais, traços do vetusto Regime da França pré-revolucionário ${ }^{7}$.

Desta sorte, é translúcido que o tratamento legal há de ser igual para todos, independente das condições e circunstâncias pessoais (igualdade como imparcialidade). "Razão pela qual, nesta perspectiva, o princípio da igualdade de certo modo correspondia à exigência da generalidade e prevalência da lei, típica do Estado constitucional de matriz liberal"8.

Em síntese! Tal fato, além de ter se tornado um marco no estudo do Poder Constituinte, trouxe à baila uma luta pela igualdade, um dos standards

\footnotetext{
3. 4 de julho de 1789.

4. Aprovado em 26 de agosto de 1789 e votado, em caráter definitivo, na data de 2 de outubro daquele ano.

5. Art. $1^{\circ}$ de tal documento.

6. A partir deste momento, têm-se a positivação dos direitos tidos como inerentes ao homem, que, até dado instante, se encontravam mais afeiçoados a reivindicações políticas e filosóficas do que as normas jurídicas obrigatórias, exigíveis judicialmente.

7. DÍEZ-PICAZO, Luís María. Sistema de derechos fundamentales. 2⿳a.ed. Madrid: Civitas, 2005. Pp.191-192.

8. GARCIA, Maria Glória F.P.D, Estudos sobre o princípio da igualdade. Coimbra: Almedina, 2005. Pp36-37 apud SARLET, Ingo Wolfgang; MARINONI, Luiz Guilherme; MITIDIERO, Daniel. Curso de Direito Constitucional. 2a -ed. São Paulo: Revista dos Tribunais, 2013. p.539.
}

da referida revolução (Liberté, égalité, fraternité) e que, ulteriormente, nas palavras do tcheco Karel Vasak se tornou uma das dimensões ${ }^{9}$ (in casu, $2^{\underline{a}}$ dimensão) dos direitos fundamentais.

\subsection{Teoria Valorativa}

Ocorre, entretanto, que a igualdade sempre foi um valor que andou de mãos dadas com a noção de justiça, muito embora com ela não se confunda ${ }^{10}$.

De tal arte, ante uma sociedade plural e diversificada, notou-se que a igualdade perante a lei (Teoria Paritária), fruto da revolução francesa, trazia, por vezes, certas injustiças, haja vista que nem todos indivíduos apresentam as mesmas características naturais ou, ainda, se encontram nas mesmas condições fáticas.

Por este motivo, exuma-se das cinzas (tal qual a mitológica ave fênix ${ }^{11}$ ) a Aristotélica ${ }^{12}$ ideia de tratar o igual de forma igual e os desiguais de forma desigual, na medida da desigualdade; uma vez que desde aquele período a isonomia já se encontrava atrelada ao valor justiça - ao conceder algo a cada um de acordo com seus méritos e de exigir de cada um aquilo que sua capacidade e possibilidade permitiam ${ }^{13}$.

Como prelecionou Rui Barbosa, na Oração aos Moços, "a regra da igualdade não consiste senão em quinhoar desigualmente aos desiguais, na medida em que se desigualam. Nesta desigualdade social, proporcionada à desigualdade natural, é que se acha a verdadeira igualdade.", uma vez que

9. Calha acentuar que tal divisão em dimensões é meramente acadêmica, pois, obviamente, inadequado seria segregar os direitos voltados aos seres humanos em categorias estanques.

Vale dizer, nesse passo, que as divisões realizadas pelos estudiosos só reverberam a valorização de determinados direitos em momentos históricos distintos. Até porque, didaticamente, é mais fácil lidar com celeumas em tomos administráveis, bem como, por demais, estatisticamente as discussões fragmentadas apresentam uma melhor absorção do conteúdo exteriorizado.

10. BOBBIO, Norberto. Igualdade e Liberdade. Trad. Carlos Nelson Coutinho. $2^{a}$.ed. Rio de Janeiro: Ediouro. p.14 .

11. Pássaro oriundo da mitologia grega que, quando morria, entrava em autocombustão, vindo a renascer, vindouramente, das próprias cinzas.

12. 384.a.C a 322 a.C.

13. ARISTÓTELES. Ética a Nicômaco. Os pensadores. São Paulo: Abril Cultural, 1979. p.129. 
"tratar com desigualdade a iguais, ou a desiguais com igualdade, seria desigualdade flagrante, e não igualdade real ${ }^{14}$."

Ou seja, ao invés de uma igualdade absoluta em todos planos, exsurge uma Teoria Valorativa, apta a atingir uma igualdade fática ${ }^{15}$ (material) por intermédio de um dosador de diferenças que traz em seu bojo uma função de "auxiliar a discernir entre desigualizações aceitáveis e desejáveis" daquelas "que são profundamente injustas e inaceitáveis"16.

Decerto, com a exigência de critérios razoáveis e justos (fins constitucionalmente protegidos), há uma compensação das desigualdades, sob o pálio da premissa de que "se não houver uma razão suficiente para a permissibilidade de um tratamento desigual, então o tratamento igual é obrigatório"17.

Com essa tônica, e pelo fato de a isonomia ser um elemento estruturante do sistema global - conjugada dialeticamente com as dimensões liberais, democráticas e sociais inerentes ao conceito de Estado de direito democrático e social $\frac{18}{2}$ -, o princípio da igualdade foi revalorado no plano internacional, de modo que a Teoria Valorativa foi inserida em diversos tratados e convenções (v.g. Declaração Universal de Direitos Humanos ${ }^{19}$, Pacto Internacional de Direitos Civis e Políticos ${ }^{20}$, Convenção Americana de Direitos Humanos ${ }^{21}$, etc),

14. BARBOSA, Rui. Oração aos moços. São Paulo: Martin Claret, 2003. p.19.

15. MIRANDA, Jorge; MEDEIROS, Rui. Constituição portuguesa anotada. Coimbra: Coimbra, 2005. Vol.I. p.120.

16. VIEIRA, Oscar Vilhena. Direitos fundamentais: Uma leitura da jurisprudência do STF. São Paulo: Malheiros, 2006. P.285 apud. NOVELINO, Marcelo. Manual de Direito Constitucional: volume único. 8a.ed. São Paulo: Método, 2013. p.476.

17. ALEXY, Robert. Teoria dos direitos fundamentais. São Paulo: Malheiros, 2008. p.411.

18. CANOTILHO, J.J. Gomes; MOREIRA, Vital. Constituição da República Portuguesa anotada - Arts. $1^{\circ}$ a 107.‥ 4a.ed. Coimbra: Coimbra, 2007. Pp.336-337.

19. 10 de dezembro de 1948. Art.VII: "Todos são iguais perante a lei e têm direito, sem qualquer distinção, a igual proteção da lei. Todos têm direito a igual proteção contra qualquer discriminação que viole a presente Declaração e contra qualquer incitamento a tal discriminação"

20. 16 de dezembro de 1966. Art.26.

21. 22 de novembro de 1969. Art.24. bem como, pelo efeito prisma, em diversas outras Constituições Nacionais.

\section{DA INFORTUNA DISCRIMINAÇÃO ${ }^{22}$}

Nessa vertente, a igualdade, por ser um direito inerente a todo ser humano (como a liberdade ${ }^{23}$ ), se tornou um direito fundamental. Até porque, trata-se de um valor indissociável à dignidade humana, vinculada a noção de que (de modo universal) todas as pessoas sejam tratadas com igual respeito e consideração.

Calha rememorar, contudo, que apesar da presente codificação do direito à igualdade em diversos ordenamentos pós-revolução francesa, historicamente, o ser humano tende a se vincular a diferenças, as empregando, inclusive, como fonte de discriminação (infelizmente!).

Tão só como recordação, é possível trazer à luz as discriminações havidas (e, ainda, vividas) por motivos de:

\section{a) Religião.}

Uma das discriminações mais antigas, e que se estende até os dias hodiernos.

Para ilustrar, podemos ponderar a intensa perseguição de cristãos, que hoje é feita muitas vezes por países de gênese islâmica.

22. "Toda distinção, exclusão, restrição ou preferência que tenha por objeto ou resultado prejudicar ou anular o exercício, em igualdade de condições dos direitos humanos e liberdades fundamentais nos campos político, econômico, social, cultural e civil ou em qualquer outro campo. Logo, a discriminação significa sempre desigualdade." (PIOVESAN, Flávia. Ações afirmativas da perspectiva dos direitos humanos. Cadernos de pesquisa. v.35 $n^{\circ} .124$, jan/abr.2005. p.48).

23. Desmiúde! Ambos conceitos, que se encontram interligados desde a revolução francesa, não são isentos de tensões (ainda que se complementem e tragam um equilíbrio entre as posições fundamentais de todos os indivíduos). E que a liberdade (e os direitos da liberdade) garante ao indivíduo o direito a diferença e a desigualdade, o que sobeja em um potencial conflito entre a pretensão de liberdade na esfera da vida social, por um lado, e, por outro uma exigência de igualdade social. (KLOEPFER, Michael. Verfassungsrecht II - Grundrechte. München: C.H. Beck, 2010. p.199 apud SARLET, Ingo Wolfgang; MARINONI, Luiz Guilherme; MITIDIERO, Daniel. Ob.cit. p.541). Noutro dizer! "A exigência política de maior liberdade social possível conflita com a exigência política de maior igualdade social possível, visto que a liberdade social também é a liberdade do mais forte e a igualdade social é justamente a igualdade de oportunidades por parte do mais fraco". (PIEROTH, Bodo; SCHLINK, Bernhard. Grundrechte, Staatsrecht II. 20ª.ed. Heidelberg: C.F. Müller, 2004. p.108 apud idem ibidem.). 
É que, logo no eclodir da religião cristã, houve uma verdadeira caça destes por judeus (de cuja religião o Cristianismo era visto como uma ramificação) e pelos imperadores do Império Romano (que controlavam grande parte das terras onde o cristianismo primitivo se distribuía) - estes, diga-se en passant, muitas vezes se aproveitavam dos cristãos capturados para realizar a alegria de sua sociedade, uma vez que eles eram colocados nos coliseus para vivenciarem batalhas ou serem degustados por leões.

Do outro cunho da moeda, na época das trevas $^{24}$ (Idade Média), no período das inquisições ${ }^{25}$, a Igreja Católica, visando combater o sincretismo religioso, responsabilizava qualquer indivíduo dotado de credos distintos daqueles exigidos como hereges.

Como consequência, delações anônimas conduziram milhares de pessoas tidas como feiticeiras, seguidores de Satã, a arderem como achas vivas em fogueiras ${ }^{26} \mathrm{ou}$, ainda, em momento posterior, a passarem por árduas provas (Ordálias ou Juízos de Deus) das quais os réus deveriam sair com vida, incólumes ou ilesos por graça divina - já que a função do pretor era desempenhada pelo Criador do Universo.

24. Tal tipologia, que traduz em sua entranha o debate entre a luz e a escuridão, foi trazida da expressão saeculum obscurum, de Caesar Baronius em 1602.

25. Tratava-se, em verdade, de um tribunal religioso, competente para julgamento das heresias religiosas ou crimes contra a fé cristã. Fôra instaurado no ano de 1200 pelo Papa Inocêncio III, no perfazer da guerra contra os albigenses. Como é notório, sequer havia direito ao réu de defesa, uma vez que, como se lapidava o pensamento da época, "se o imputado era inocente, não precisava de defensor e, se culpado, era indigno de defesa" (TOURINHO FILHO, Fernando da Costa. Processo penal. 8ª.ed. São Paulo: Saraiva, 1986. p.93). Assim, de forma autoritária, cabia ao pretor o cargo de julgar e acusar, num processo arbitrário e violento. Extrai-se, daí, que ao magistrado tudo era possível. Quiçá, ainda, cumpriria a ele desempenhar as funções de 'defesa' do acusado. Nessa senda, se engendra o princípio de CARPSOVIO: judex supplere debet defensiones ex officio. (MARQUES, José Frederico. Estudos de direito processual penal. Rio de Janeiro: Forense, 1960. p.23).

26. Mero adendo de cunho cultural. Naquele período, as pessoas que traduziam certa aptidão com o braço esquerdo, denominadas de sinistras (canhotas em italiano), eram equiparadas a feiticeiros. Portanto, ardiam vivas como brasa na fogueira. Com o perpassar dos tempos, o vocábulo fôra introduzido em nosso idioma, significando "que prevê acontecimentos ruins, funesto, agourento; (...) que causa o mal; terrível, assustador; desastre, acidente, dano" (HOUAISS, Antônio; VILLAR, Mauro de Salles e FRANCO, Francisco Manoel de Mello. Minidicionário Houaiss da língua portuguesa. $2^{\text {a }}$ edição. Rio de Janeiro: Objetiva, 2004. p.683). Desta feita, se atentarmos a antinomia existente entre a palavra canhestro - desajeitado, sem habilidade - e destreza - agilidade de movimentos, aptidão, habilidade -, nota-se uma aversão, empregada de maneira inconsciente hoje em dia, oriunda daquela época.
Como exemplificação destes Juízos de Deus, temos: a) o ato de o réu (eventual herege) caminhar sobre brasas durante algum tempo ou colocar a mão em um braseiro, de modo que sua resistência às chamas seria determinante de sua sinceridade; b) em temperatura inversa, também se encontrava o teste da água fria, onde o réu era lançado em um reservatório de água. Se submergisse, era tido como inocente ou titular do direito pleiteado; caso voltasse à tona, seria ele considerado culpado $^{27}$; c) outrossim, havia a prova das serpentes. 0 herege era colocado entre répteis, acreditando-se que somente seria picado se efetivamente fosse um criminoso ${ }^{28}$; d) como derradeiro exemplo, na antiga Pérsia, para se descobrir a verdade, havia a denominada prova do arroz. Para tanto, a parte deveria rapidamente engolir certa quantidade desse alimento, ainda cru. Se, ao final, não conseguisse ela digerir o cereal - antes de pontuar certa declaração -, estaria a parte indo em sentido antípodo ao da verdade ${ }^{29}$.

Recentemente, no século passado, houve um momento histórico em que a lei se tornou a única fonte de direito. 0 jus se reduziu a lex ${ }^{30}$. Debelou-se, para muitos jurisconsultos daquela época, a necessidade de compreensão dos demais ramos do saber, como a sociologia, história, filosofia, e todas outras matérias que alicerçavam o âmago daquilo exposto in lege.

Emergiu, desta forma, um Estado Legalista ${ }^{31}$ que, pautado na pura teoria do direito ${ }^{32}$, começou

27. MORAIS, Paulo Herber de; LOPES, João Batista. Da prova penal. Campinas: Julex Livros LTDA., 1978. p.12;

28. Idem.

29. MARQUES, José Frederico. Estudos de direito processual penal. Ob.cit. p.291.

30. FERRAZ, Tércio Sampaio. Introdução ao Estudo do Direito. $3^{a}$ edição. São Paulo: Editora Atlas, 2001. p.24.

31. Na evolução dos Estados, o positivismo - de regras impostas para dirimir conflitos e pacificar pessoas - passou a ser empregado como instrumento de justificação de regimes autoritários. Como pontificavam Benito Mussolini e Rocco, "Ia dottrina fascista nega il dogma della sovranitá populare, che é ogni giorno smentido della realtá, e proclama in sua vece il dogma della sovranitá dello Stato" (MALUF, Sahid. Teoria geral do Estado. Revista e atualizada pelo Prof. Miguel Alfredo Malufe Neto. 26a .ed. São Paulo: Saraiva, 2003. p.141).Cumpre ressaltar. $O$ Estado se tornou criador exclusivo do direito e da moral, não encontrando limites morais ou materiais à sua autoridade. Por isso, dizia-se, inclusive, que todos os cidadãos e seus bens pertenciam ao Poder Público. É que, como reflete Thomas Hobbes, Auctoritas, non veritas facit legem. Ou seja, a lei é vontade, não vale por qualidades morais e lógicas, mas precisamente como ordem. (MARINONI, Luiz Guilherme. Teoria geral do processo. 3a ed. rev. e atual. São Paulo: Revista dos Tribunais, 2008. v I. p.27). Daí, aquela máxima: "Tudo dentro do Estado, nada fora do Estado, nada contra o Estado". 
a elaborar leis com diversas arbitrariedades e abusos, se intrometendo, exempli gratia, nos mais recônditos círculos da vida humana.

Aflorou, daí, o Partido Nacional Socialista ${ }^{33}$ (National Sozialist / Estado Nazista), sectário e intolerante como as demais ditaduras, que absorveu inteiramente a personalidade humana e anulou todos os valores individuais.

Como um de seus escopos, houve a promoção da busca por judeus - que eram submetidos a: a) trabalhos forçados em funestos campos de concentração (v.g. Auschwitz-Birkenau, Dachau, Buchenwald, dentre outros 20 mil); b) experimentos, como os da ignóbil figura de Joseph Mengele (o anjo da morte / Todesengel) e de Sigmund Rascher (médico da força aérea / Deutsche Luftwaffe); e c) a mortes nefastas, em campos de extermínio, voltados para o excídio em massa muitas vezes realizado por envenenamento em câmaras de gás.

Com o findar da $2^{\text {a }}$ Grande Guerra Mundial, o saldo foi de 50 milhões de mortos, sendo 6 milhões só de judeus.

\section{b) Raça}

A discriminação racial, pari passu a religiosa, foi marcante no perpassar dos tempos. E, de igual maneira, é realizada com certa frequência até a presente data.

Ora, não há como olvidar o período da recente escravatura, onde africanos eram retirados

32. Nos lapidados manifestos do pranteado HANS KELSEN, "quando designa a si própria como 'pura', teoria do Direito, isto significa que ela se propõe a garantir um conhecimento apenas dirigido ao Direito e excluir deste conhecimento tudo quanto não pertença ao seu objeto, tudo quanto não se possa, rigorosamente, determinar como Direito". (KELSEN, Hans. Teoria pura do direito. 5a edição. São Paulo: Editora Martins Fontes, 1996. p.1).

33. Amiúde. Deve-se salientar que, naquele período histórico, a Europa se encontrava conquistada pelo galanteador luminar totalitário. Não por outra razão, referido pensamento se difundiu com certa celeridade por aquele continente. Antes mesmo da assunção ao poder de ADOLF HITLER (o führer), acoroçoado por seu partido Nazista BENITO AMILCARE ANDREA MUSSOLINI (o Duce), já havia alicerçado os ideais do Facismo na Itália. Ademais, não se pode olvidar, outrossim, da participacão de ANTÓNIO DE OLIVEIRA SALAZAR, em Portugal, e FRANCISCO PAULINO HERMENEGILDO TEÓDULO FRANCO Y BAHAMONDE, na Espanha. coercitivamente de suas terras, de seus lares e do seio de sua família. Como mercadorias, atravessavam o Atlântico rumo ao novo mundo, onde seriam adquiridos (como se propriedades fossem) de acordo com sua procedência, idade ou, ainda, suas condições físicas e habilidades profissionais.

Em verdade, muitos aqui nem chegavam. Eram vitimados pelos tratos que recebiam dentro dos navios, uma vez amontoados em condições desumanas. Outros tantos, faleciam em razão de doenças, como o escorbuto (scorbutus), que além da tumefação purulenta das gengivas e dores nas articulações, causava a não cicatrização das feridas e hemorragias. Aos mortos, restava serem lançados ao mar.

Aos que aqui chegavam, a vida terrena se encontrava cheia de sacrifícios vindouros. É que, além do angustiante percurso até então realizado, os escravos em terra eram vendidos e segregados de seus companheiros de viagem ou do restante de suas famílias. Recebiam, a partir deste momento, destinos diferentes, mas com igual condição de vida: a desumana.

Eram, nessa vereda, submetidos a trabalhos forçados nas fazendas de cana ou nas minas de ouro. Sem períodos de descanso ou outras benesses, chegavam a trabalhar de quatorze a dezesseis horas corridas. Para dormir, restavam as senzalas, sujeitos ao frio, umidade e a pouca higiene. E, ademais, com o escopo de evitarem fugas, mal podiam se movimentar, uma vez que tinham que descansar acorrentados.

Aos "fracos", que não suportavam as condições impostas, bem como aqueles que se contrapunham a este sistema, sobejava o castigo físico, geralmente perpetrado por açoites até que o escravo perdesse seus sentidos. Havia, ainda, outros mecanismos sancionatórios, como a tortura psicológica realizada pela máscara de flandres (que impedia os escravos de beberem) e a pena de morte.

Infeliz, de mais a mais, era a vida das escravas, pois, além da lida similar àquela já professada, muitas vezes eram subjugadas pelos senhores da terra (ou seus capatazes) a com eles praticarem relações sexuais forçadas.

A escravidão, tamanho o trato animalesco realizado, chegou a um ponto insustentável. Deste modo, diversas leis no mundo vieram a conceder a libertação do escravagismo. 
O Brasil, não estanque a este fenômeno global, traduziu este processo de maneira paulatina, com a concreção da: a) Lei Eusébio de Queirós $\left(1850^{34}\right)$, fruto de pressão da Inglaterra pelo Bill Aberdeen, que punia os traficantes de escravos; b) Lei do Ventre Livre $\left(1871^{35}\right.$ ), que dava liberdade aos filhos dos escravos que nascessem a partir daquele ano; c) Lei dos Sexagenários / Lei SaraivaCotegipe $\left(1885^{36}\right)$, que concedia a liberdade aos maiores de sessenta anos; e, por fim, d) Lei Áurea $\left(1888^{37}\right)$ que, assinada pela Princesa Isabel ${ }^{38}$ e pelo ministro da Agricultura Rodrigo Augusto da Silva, aboliu o escravismo em nossa pátria.

Nos Estados Unidos da América, a libertação da escravidão se fez com a Proclamação da Emancipação (1863), realizada por Abraham Lincoln no transcorrer da guerra da Secessão (guerra civil americana), onde os estados escravistas do sul (Confederados) almejavam a separação (secessão) dos demais estados do norte.

Ocorre, entrementes, que com a vitória dos estados do norte, somada a ocupação militar dos estados do sul (até 1877), fomentou-se naquela região vencida o surgimento de grupos com a finalidade de segregação racial, atuando, muitas vezes, por intermédio da perseguição violenta de negros (antigos escravos).

Dentre tantos grupos, o de maior relevância foi o da Ku Klux $\mathrm{Klan}^{39}$ (KKK), que, inicialmente (1865), tinha por finalidade obstar a integração dos negros recém-libertados. Com o advento temporal, tal desiderato permutou para uma eventual supremacia branca, acarretando a concreção de diversas atrocidades, indo de linchamentos a execuções sumárias de afrodescendentes - precipuamente.

Mutatis mutandis, no berço do mundo, a África do Sul também reverberou a segregação

34. 4 de setembro de 1850.

35. L. 2.040, de 28 de setembro de 1871.

36. L. 3.270, de 28 de setembro de 1885

37. Lei Imperial $n^{\circ} 3.353$, de 13 de maio de 1888.

38. Isabel Cristina Leopoldina Augusta Micaela Gabriela Rafaela Gonzaga de Bragança e Bourbon.

39. Em seu auge, por volta de 1920, chegou a possuir cerca de 4 milhões de membros. racial pelo regime do Apartheid (1948-1994), onde uma divisão dos habitantes em grupos raciais era imposta.

O direito de voto sopesava a uma minoria branca, detentora do poder político e econômico do país. Aos negros, grande maioria, recaia tão só a obrigação de obedecer a legislação separatista.

Verbi gratia: a) a Lei de Áreas de agrupamento (1950), que de forma coercitiva retirou muitos cidadãos de suas residências, haja vista a impossibilidade de raças distintas permanecerem vivendo lado a lado - delimitouse, destarte, a localidade em que cada raça deveria permanecer; b) a Lei da Imoralidade, que no mesmo ano tornou crime relações sexuais entre pessoas de raças diferentes; c) a Lei de Reserva dos Benefícios Sociais (1953), que trazia em seu corpo a reserva de locais públicos para cada raça (e.g. como placas, em praças, com a inscrição: "somente para brancos"), etc.

Tal fato perdurou por quase cinquenta anos, vindo a findar por intermédio de um plebiscito fomentado pelo então presidente Frederick Willem de Klerk (ganhador do Nobel da Paz, em 1993, ao lado de Nelson Mandela), onde 69\% da população branca deliberou no sentido de debelar tal regime.

Nos tempos contemporâneos, a discriminação racial ainda se faz presente. No primeiro semestre do ano de 2014, três fatos ocorreram em regiões distintas e eclodiram no epicentro dos noticiários globais.

O primeiro episódio se deu em 12 de fevereiro de 2014. Numa partida da competição Copa Libertadores da América, em Huancayo (Peru), a torcida da equipe Real Garcilaso emitia sons de macaco toda vez que o jogador brasileiro Tinga, do Cruzeiro, relava na bola. Empós tal episódio, tamanha sua frustação, Tinga declarou: "por mim, eu deixaria de ganhar qualquer título para que não houvesse desigualdade".

Em lapso não distante, no mês de abril, dia 27, foi veiculada pela TMZ o áudio de uma conversa do dono da equipe de basquete Los Angeles Clippers, Donald Sterling, com sua namorada V.Stiviano. 0 diálogo entre ambos se restringiu a recriminação dele pelo fato de sua amada ter retirado uma foto ao lado de um negro: Magic Johnson, um 
dos maiores nomes daquele esporte. Durante o colóquio, ademais, chegou a rogar para que ela não levasse negros para assistir aos jogos do Clippers.

Como penalidade, a Liga Americana de Basquete afastou o dono da franquia da NBA uma vez que aquela não havia sido a primeira vez em que Donald Sterling se envolveu com situação similar - e, em contraproposta, nomeou Dick Parson (que é negro!) como diretor-executivo interino daquela equipe.

Enfim, por incrível que pareça, na mesma data (27 de abril), na cidade de Villarreal (Espanha), durante a partida de futebol entre os times de Barcelona e Villarreal, um torcedor local arremessou uma banana em direção ao lateral-direito da seleção brasileira, Daniel Alves. De maneira irreverente, e inesperada, o jogador abaixou-se e, depois, digeriu o alimento a ele lançado.

O jornal Marca, em data subsequente ao evento, ponderou: "convivo há 11 com a mesma coisa na Espanha".

\section{c) Sexo.}

Ainda que existentes outras discriminações a serem pontuadas (como a xenofobia, vinculada a origem das pessoas, v.g.), decidimos tratar como derradeira forma de discriminação a intolerância sexual.

É hialino, antes de tudo, que embora iguais em dignidade, o ser humano apresenta diferenças biológicas entre sexos. A genética, hoje em seu auge, está aí para desmistificar tais complexidades, determinando a razão de fenótipos tão distintos.

Entretanto, antes do exsurgir desta recente ciência, cuja terminologia só foi dada em 1908 por William Bateson (em carta direcionada para Adam Sedgewick), as diferenças havidas entre os grupos sexuais (masculino e feminino) serviam de estofo para as mais variadas discriminações.

Nesse cipoal, estudos antropológicos sustentam que nas sociedades primitivas a própria divisão laboral já era apta a indicar a vetusta visão de inferioridade feminina. Quiçá pela tônica muscular, as mulheres ficavam restritas a atividades interiores, enquanto, de outro turno, aos homens competiam as funções de caça e guerra. Nascia, assim, a origem do patriarcalismo.
Durante o Império Romano, um dos berços da civilização, a situação das mulheres piorou. Equiparadas a uma coisa, só adquiriam sua autonomia com as mortes de seu genitor e de seu marido.

Já no período da inquisição, retratado neste artigo, estima-se que entre $75 \%$ a $90 \%$ dos mortos pelos crimes de epidemia e más colheitas eram mulheres, razão pela qual, consideradas bruxas / feiticeiras, eram lançadas às fogueiras.

Tal panorama só começa a se alterar no perfazer do século XIX. Com a revolução industrial e o engatinhar do capitalismo, as mulheres, já organizadas em sindicatos, passaram a pleitear melhores salários e melhores condições de serviço. Infelizmente, para referida evolução, tão só em uma Indústria têxtil, em Nova Iorque (1857), centenas de trabalhadoras foram incineradas - situação similar, diga-se en passant, foi a razão do dia internacional da mulher se dar em março. É que, no referido mês, em 1911, um incêndio na fábrica têxtil Triangle Shirtwaist, igualmente em Nova Iorque, ceifou a vida de mais de 100 operárias, que não conseguiram se furtar em razão da precariedade do local.

De qualquer modo, é digno de nota que este caminhar pela igualdade entre homens e mulheres foi paulatino. Em 1879, as mulheres nem sequer podiam cursar nível superior. De mais a mais, o código civil de 1916, em sua origem, considerava as mulheres relativamente incapazes, havendo a necessidade de ratificação de seus maridos para que seus atos tivessem validade na órbita civil - talvez pelo fato de as ordenações Filipinas pontuarem a "fraqueza de seu entendimento".

Em 1932, por demais, a mulheres passaram a ter o direito de voto, ainda que de modo opcional, haja vista que a obrigatoriedade deste só veio em 1946 - mesmo ano, curiosamente, em que o biquíni (muito criticado) foi usado pela primeira vez pela stripper parisiense Micheline Bernardine.

Cansadas da opressão vigente, em um ato que se tornou um marco do feminismo, quatrocentas mulheres do Women's Liberation Movement (WLM) saíram às ruas em 7 de setembro de 1968, em Atlantic City (EUA), e depositaram seus sutiãs, sapatos de salto alto e espartilhos em frente ao teatro onde ocorria o concurso de Miss América - evento tido como uma forma de exploração comercial das mulheres. 
Empós denotado episódio, que recebeu o nome de "queima dos sutiãs" (apesar de nenhum deles ter sido queimado, de fato), María Estela Martínez de Perón assume a presidência da Argentina, e se torna, nesse passo, a primeira mulher a presidir um país.

Nos dias atuais, embora muitos direitos tenham sido alcançados (como a igualdade entre homens e mulheres, art. $5^{\circ}, \mathrm{I}, \mathrm{CRFB}$; igualdade de direitos e deveres entre os cônjuges, art.226, §5 $5^{\circ}$, CRFB, etc), é necessário professar que a desigualdade sexual se faz presente, porém, agora, implicitamente.

Com espeque em quadros estatísticos recémavaliados, ainda que as mulheres alcancem $41 \%$ da força de trabalho atual, tão só $24 \%$ dos cargos de chefia existentes são ocupados por elas.

Ademais, apesar de nossa bíblia política proibir diferença de salários, de exercício de funções e de critério de admissão por motivo de sexo (art. $7^{\circ}, \mathrm{XXX}, \mathrm{CRFB}$ ), no que concerne ao salário, mesmo exercendo a mesma função, é apontado que as mulheres recebem $71 \%$ do valor adquirido pelos homens.

\section{OS INSTRUMENTOS DE EFETIVACCÃO DA IGUALDADE E NÃO DISCRIMINAÇÃ O}

De maneira sucinta, é digno de nota que apesar de no jogo de xadrez o rei e o peão voltarem para a mesma caixa, as discriminações continuam a se perfazer (ainda que proibidas no direito das gentes - v.g Convenção sobre a eliminação de todas as formas de discriminação racial $^{40}-\mathrm{e}$ em nossa Constituição - v.g. art. $5^{\circ}$, XLI, CRFB ${ }^{41}$ ) .

Deste modo, não basta que a igualdade seja assegurada tão só empós a morte das pessoas. Fazse necessário que além dos textos constitucionais (ou de tratados, convenções), seja garantida uma igualdade palpável.

\footnotetext{
40. Resolução 1904 da Assembleia Geral da ONU, de 20 de dezembro de 1963. Que, desde seu preâmbulo, traduz o fato de a "doutrina de superioridade baseada em diferenças raciais é cientificamente falsa, moralmente condenável, socialmente injusta e perigosa, inexistindo justificativa para a discriminação racial, em teoria ou prática, em lugar algum."
}

41. "A lei punirá qualquer discriminação atentatória dos direitos e liberdades fundamentais".
Razão pela qual, emergem veículos aptos a garantir uma isonomia concreta, seja no plano interno ou no plano internacional (Droit des gens / Volkerrech / Law of Nations), de acordo com duas estratégias: a) promocional, que visa propulsionar o avanço do direito a igualdade; e b) repressiva / punitiva, cujo objetivo é proibir, punir e, assim, eliminar as diferenças.

Verbera-se desta forma que ambos os mecanismos se complementam, sendo interdependentes um do outro.

Como denota Flávia Piovesan ${ }^{42}$, a medida repressiva (fundamental para que se garanta o pleno exercício dos direitos civis e políticos, como também dos direitos sociais e econômicos e culturais) é, por si só, insuficiente. Daí, a sua combinação com a vertente promocional se faz indispensável, com a inserção e inclusão de grupos socialmente vulneráveis nos diversos espaços sociais.

É nessa toada, diga-se de passagem, que veremos a perpetração de tais instrumentos de efetivação da igualdade - tanto no ordenamento jurídico interno como numa esfera macro, pelo direito das gentes.

\subsection{A efetivação da igualdade no plano interno}

\subsubsection{Ações afirmativas / Discriminações positivas}

Conforme visto até aqui, abordar o direito à igualdade é concretizar comparações - com o estabelecer de um ponto de referência para tanto. Isso porque, deste modo, se torna possível vislumbrar as desigualdades e concretizar, na medida do possível, medidas diferenciadas tendentes a debelar ${ }^{43}$ ou, ao menos, atenuar as diferenças havidas (Teoria valorativa).

Decerto, desmiuda-se, nesse ponto, a obrigação do Poder Público de distribuir direitos

\section{Ob.cit. p. 49 .}

43. Preleciona Joan Scott que a luta pela igualdade não significa "ausência ou eliminação da diferença, mas sim o reconhecimento da diferenca e a decisão de ignorá-la ou de levá-la em consideração" (SCOTT, Joan. O enigma da igualdade. Estudos Feministas. Florianópolis, $n^{\circ} 13$ (1), jan./abr., 2005. p.15). 
e benefícios voltados à criação de condições materiais de igualdade (isonomia distributiva), uma vez que a própria Magna Carta traçou como um dos objetivos fundamentais da República Federativa do Brasil (art. $3^{\circ}$, III, CRFB) a adoção de medidas tendentes à redução das desigualdades sociais (art.170, VII, CRFB) e regionais (arts.43; $165, \S 7^{\circ}$; e $\left.170, \mathrm{VII}, \mathrm{CRFB}\right)$.

Cumpre dizer! 0 direito à igualdade apresenta uma perspectiva positiva, impelindo o Poder Público a promover: a) igualdade entre pessoas em determinadas situações (arts. $7^{\circ}, \mathrm{XX}$; e 37, VIII, CRFB); b) o acesso igual às prestações de bens, serviços, etc; bem como c) a concreção de discriminações positivas / ações afirmativas, onde há uma atuação estatal (seja na esfera fática ou normativa) focada na imposição constitucional de uma igualdade de oportunidades.

Nessa alheta, com o fito de se alcançar uma isonomia concreta, emergem determinadas políticas públicas (ou programas privados), ainda que de caráter temporário ${ }^{44}$, com o desiderato de diminuir as desigualdades. A esse fenômeno, deuse o nome de ações afirmativas (fruto da Teoria do Impacto Desproporcional, elucubrada pela jurisprudência Estadunidense).

Noutra palavra, sob a concessão de algum tipo de vantagem compensatória (daí, sua outra tipologia: discriminação positiva / inversa), as ações afirmativas são medidas jurídicas adotadas em favor de grupos objetivamente discriminados de forma injustificada (v.g. hipossuficiência econômica, debilidade física, por cunho racial, etc) e podem sopesar em favor de minorias (v.g. deficientes) ou maiorias (v.g. mulheres), desde que proporcionando um favorecimento temporário até se atingir a isonomia concreta.

Traduzem, assim, um poderoso instrumento de inclusão social. São medidas especiais que tendem a acelerar o processo pela igualdade, muitas vezes remediando as condições resultantes de um passado de discriminação.

44. A temporariedade reside no fato de as ações afirmativas, em regra, terem certo tempo de duração, uma vez que tais políticas devem ser extintas ao se alcançar o resultado por elas pretendido Digno de nota, todavia, a existência de certas excecões a ela (regra da temporariedade). Isso porque, as políticas públicas direcionadas aos grupos indígenas ou pessoas com deficiência tem caráter permanente (NOVELINO, Marcelo. Ob.cit. p.485).
Com a justificação constitucional de galgar uma igualdade fática, cumpre uma finalidade pública essencial para o projeto democrático: assegurar a pluralidade social (art.1 $\left.1^{\circ}, \mathrm{V}, \mathrm{CRFB}\right)$. Isso, além de cunhar a ideia de que a igualdade deve "moldar-se no respeito à diferença e à diversidade" 45 .

Crível que, para o emprego dessas políticas compensatórias, há de se preencher alguns requisitos. Por intermédio de um estudo prévio, é imprescindível valorar as peculiaridades locais. De igual maneira, deve-se analisar a condição de os beneficiários destas ações não possuírem mecanismos de integração num futuro próximo, de modo que a discriminação seja tamanha a ponto de dificultar substancialmente (ou, talvez, impedir) o acesso destes grupos as mais variadas esferas sociais ${ }^{46}$.

Isso porque, desta forma, dificulta-se a existência de "medidas aparentemente neutras sob o ponto de vista discriminatório, quando de sua aplicação" e que trazem, em seu cerne, "efeitos nocivos e particularmente desproporcionais para determinados grupos de pessoas" ${ }^{\prime 7}$. Medidas, estas, aptas a acarretarem uma discriminação reversa, haja vista que poderiam prejudicar outros grupos de modo a colocá-los em situação de desvantagem perante os demais segmentos sociais, fomentando, ao invés da igualdade almejada, uma real ojeriza por aqueles beneficiados.

Id est, hoje em dia não se discute mais a possibilidade de serem realizadas ações afirmativas, dada sua concreção positiva nos Estados Unidos da América, Europa e, hodiernamente, no Brasil. Daí, o único ponto, ainda, que resta a ser discutido são os critérios utilizados (e, eventualmente, o modo) para se aferir o rol de beneficiários destas medidas.

Transposto este introito, calha adentrar nas principais políticas públicas (ações afirmativas) aplicadas em nossa pátria.

\section{PIOVESAN, Flávia. Ob.cit. p.50}

46. KAUFMANN, Roberta Fragoso Menezes. Ações afirmativas à brasileira: necessidade ou mito? Uma análise histórico-jurídicocomparativa do negro nos Estados Unidos da América e no Brasil. Porto Alegre: Livraria do Advogado, 2007. p.221. apud NOVELINO, Marcelo. Ob.cit. p.484

47. SARLET, Ingo Wolfgang; MARINONI, Luiz Guilherme; MITIDIERO, Daniel. Ob.cit. p.553. 
a) Em favor de grupos raciais.

Ao lado das bolsas de estudo e dos ensinos profissionalizantes, exsurge como uma das principais ações afirmativas o sistemas de cotas, que consiste na reserva de um percentual de vagas para grupos discriminados (v.g. 20\% das vagas oferecidas nos concursos públicos realizados pela administração pública federal devem ser destinadas a candidatos negros ${ }^{48}$; a cota eleitoral de gênero, que dispõe que cada partido ou coligação preencherá o mínimo de $30 \%$ e o máximo de $70 \%$ para candidaturas de cada sexo ${ }^{49}$, etc).

Tal tema, diga-se en passant, ganha projeção quando as referidas cotas são destinadas a grupos raciais. Até porque, estatisticamente, o Brasil, em razão do largo período de escravatura e da miscigenação dela havida, é composto em sua maioria por cidadãos negros e pardos.

De qualquer modo, apesar do maior contingente da população brasileira ser afrodescendente, as referidas cotas não se sedimentam em solo pacífico, isento de críticas. Em verdade, há verdadeira e acalorada digladiação acadêmica sobre referido tema.

Nas trincheiras doutrinárias, desta sorte, apresentam-se dois posicionamentos, com ponderações válidas para ambos luminares ${ }^{50}$.

Em um primeiro momento, contrário ao sistema de cotas, há o raciocínio de que tais medidas apresentam um cunho imediatista, sem aptidão para execrar o problema da disparidade racial de modo definitivo. Ou seja, se trataria de um mero sistema de maquiagem do problema, ao invés de um instrumento para sua real solução.

De mais a mais, ainda para denotado elucubrar, as reservas de vagas viriam a vilipendiar os

48. L.12.990, de 10 de junho de 2014.

49. Art.10, §3ํㄹ da L.9504, de 30 de setembro de 1997.

50. Se ao trazer fundamentos para ambos os lados é "politicamente incorreto", necessário se faz observar os sábios dizeres de Martin Luther King - pastor negro que foi preso por falar sobre o racismo. "A covardia coloca a questão: é seguro? O comodismo coloca a questão: é popular? A etiqueta coloca a questão: é elegante? Mas a consciência coloca a questão: é correto? E chega uma altura em que temos que tomar uma posição que não é segura, não é elegante, não é popular, mas o temos de fazer porque a nossa consciência nos diz que é essa a atitude correta". princípios constitucionais da igualdade, da não discriminação e do devido processo legal. Isso porque, haveria indiscutível lesão ao direito de pessoas não inseridas no grupo beneficiado por estas ações, fato que sobejaria na indesejada discriminação reversa.

Como lastro de tal pensar, traz-se a ilustração do caso Blake (regentes da Universidade da Califórnia vs. Allan Blake), julgado em 1977 pela Suprema Corte norte-americana. É que, conforme consta, ante a reserva de 16 vagas das 100 (da escola de medicina) para membros de minoria em desvantagem educacional e econômica, se sustentou que "todo cidadão tem o direito constitucional de não sofrer desvantagem, pelo menos na competição por algum benefício público, porque a raça, religião ou seita, região ou outro grupo natural ou artificial ao qual pertença é objeto de preconceito ou desprezo ${ }^{51 "}$.

Vale pontuar. Para esta percepção, as cotas raciais fomentariam o racismo e ódio em relação aos negros.

Caso similar é aquele refletido por William Douglas $^{52}$, no que concerne ao sistema de cotas para concursos públicos. É que, ainda que favorável ${ }^{53}$ às cotas para faculdades, estágios e até em programas de bolsas, para ele, não há como elas serem observadas em concursos públicos, sem que haja o fomento a uma discriminação reversa.

Em seu pensar, diferente do que se crê, as cotas para os concursos não traduzem uma evolução das cotas existentes para as universidades. Isso porque, enquanto as primeiras preparam para competir, as outras debelam a competição, onde ela é indispensável a bem do serviço público e dos seus destinatários. Ora, o cargo público não seria forma de ajudar alguém, mas "para alguém (servidor público) ajudar o cidadão". De tal arte, almeja-se o mais preparado para aquela função, razão da existência de um concurso público.

51. DWORKIN, Ronald. Uma questão de princípio. São Paulo: Martins Fontes, 2000. p.448. apud NOVELINO, Marcelo. Ob.cit. p. 485 .

52. DOUGLAS, William. A propósito das cotas nos concursos públicos. Disponível em: shttp:www.atualiadesdodireito.com.br/ williamdouglas/2014/04/02/a-proposito-das-cotas-nos-concursos-publicos $\geq$, Acesso em: 14 de junho de 2014.

53. William Douglas é membro da Educadro, Oscip franciscana que luta pela inclusão social. 
Ademais, prossegue em seu luminar, o correto é assegurar uma meritocracia nessa situação. Pois, se assim não o for, o negro aprovado em um concurso público carregará a pecha, por toda carreira, de não ser bom o suficiente, mas mero aprovado pelas cotas.

De qualquer modo, antes de se permutar para o outro cunho da moeda, se faz necessário trazer algumas ponderações extremamente válidas:

a) A limine, imprescindível observar a inexistência de critérios objetivos válidos para asseverar se determinado indivíduo é, ou não, negro.

Exemplifica-se! No ano de 2007, dois irmãos gêmeos (univitelinos), filhos de pai negro e mãe branca, se inscreveram para o vestibular da Universidade de Brasília (UnB) utilizando o sistema de cotas (com o fundamento de que a nota de corte dos cotistas seria mais baixa). Ocorre, entretanto, que uma banca formada para a avaliação daqueles que seriam beneficiados pela ação afirmativa, ao analisarem as fotos anexadas na ficha de inscrição, julgaram que um dos irmãos (Alex) seria merecedor daquela política compensatória, enquanto o outro (Alan) não.

b) Por demais, o critério racial, por si só observado, viria a colaborar precipuamente com negros de poder aquisitivo elevado, que tiveram melhores condições educacionais por frequentarem escolas de melhor qualidade.

Tal fato, de clareza solar, traria a injustiça de afastar aqueles mais necessitados dentre eles. Razão pela qual, há necessidade do reexame deste programa. Daí, a melhor solução, proposta pelo Min. Gilmar Mendes, é a de que o critério racial deveria ser cumulado com algum outro requisito, como a hipossuficiência econômica (por exemplo), de modo a evitar situações indesejáveis onde negros de boas condições socioeconômicas e de estudo se valham da política compensatória, numa "atitude arrivista, de aproveitar-se do modelo para aboletar-se em vagas" e "esquivar-se da concorrência legítima" ${ }^{54}$.

54. STF - RE 597.285/RS, rel. Min. Ricardo Lewandowski (09.05.2012). (Informativo 665/STF). De igual modo, vide: STF ADPF 186/DF, rel. Min. Ricardo Lewandowski (25 e 26.04.2012).
Em posição contraposta a ora esboçada, se apresenta o outro cunho da moeda: o elucubrar favorável às cotas raciais.

Num primeiro argumento (justiça compensatória), é necessário observar que o abismo social existente entre a população branca e negra não se deve necessariamente à formulação de políticas abertamente discriminatórias empós a Lei Áurea e a proclamação da república. Ocorre que, no momento em que o ex-escravo, recém liberto, adquire sua alforria (manumissão), todos papéis e posições na ordem social já estavam determinados por preferências de cor.

Deste modo, e também pelo extenso período de escravagismo, as ações afirmativas havidas pelo sistema de cotas raciais tentam compensar injustiças pretéritas cometidas, por particulares ou pelo governo, em face de fantasmas do passado.

Ou seja, com pálio num dos objetivos fundamentais da República Federativa do Brasil, que preconiza a construção de uma sociedade livre, justa e solidária (art. $3^{\circ}$, I, CRFB), as políticas públicas realizadas por intermédio de cotas raciais visam reparar os danos perpetrados em relação aos negros, "por meio do resgate de uma dívida histórica, como no caso decorrente da escravidão" ${ }^{55}$.

Até porque, se observarmos, a maior parte do contingente daqueles desfavorecidos socioeconomicamente é composta por negros fruto da marginalização histórica pós-escravismo. Consoante pesquisa concretizada pelo o Instituto de Pesquisa Econômica e aplicada (Ipea), em um estudo publicado em 17 de novembro de 2005 sobre a desigualdade entre raças, dos $10 \%$ mais pobres da população, 64,6\% são negros (e, passados nove anos desta estatística, tal panorama pouco se alterou).

Outro argumento válido, de mais a mais, se dá justamente pelo fato de que tais indivíduos, por que não tiveram as mesmas oportunidades, não se encontram em mesmo patamar de condições que os brancos.

Razão da legítima reivindicação de, por intermédio de tais ações, buscarem benefícios, vantagens e posições que teriam possuído se não houvesse a desigualdade existente. Noutro dizer! Busca-se, por essas políticas públicas, a existência 
de uma igualdade substancial, com a redução de desigualdades fáticas, por intermédio de uma "promoção de oportunidades para aqueles que não conseguem se fazer representar de maneira igualitária ${ }^{56 "}$ (justiça distributiva).

Por derradeiro, com a distribuição de oportunidades e com a compensação das atrocidades de um passado que não pode ser esquecido, alcança-se um dos fundamentos da República Federativa do Brasil: o pluralismo social (art.1 $\left.1^{\circ}, \mathrm{V}, \mathrm{CRFB}\right)$, com uma sociedade mais diversificada, aberta, tolerante, miscigenada e multicultural.

É, portanto, aqui que reside o último argumento favorável às cotas raciais: 0 da promoção da diversidade.

Destarte, ainda que haja ponderações a serem observadas (como as feitas acima), o sistema de ações afirmativas voltadas ao benefício de grupos raciais traz em seu bojo um imperativo democrático deveras válido. Isso porque, de suas entranhas se extrai uma justiça social com carga de aliviar "um passado discriminatório e a fomentar no presente e no futuro transformações sociais necessárias" ${ }^{\prime 2}$.

b) Em favor das mulheres.

É recente a aquisição de diversos direitos e garantias para as mulheres, que, até 1932, não possuíam nem sequer direito ao voto.

Tais transformações jurídicas e normativas daí advindas exsurgiram, tão só, por intermédio de políticas públicas, que buscavam a promoção de oportunidades iguais e uma isonomia concreta, fática, entre a relação de homens e mulheres.

Foi desta forma, diga-se de passagem, que a nossa constituição passou a incorporar diversos direitos e garantias fundamentais, recebendo o ápodo de Cidadã por Ulysses Guimarães (que presidiu a Assembleia Nacional Constituinte).

56. Idem. p.225. apud idem ibidem.

57. PIOVESAN, Flávia. A compatibilidade das cotas raciais com a ordem internacional e com a ordem constitucional brasileira. Disponível em: $\leq h t t p: w w w . s t f . j u s . b r / a r q u i v o / c m s /$ processoAudienciaPublicaAcaoAfirmativa/anexo/cotasSTF2010rev1_Flavia_Piovesan.doc z. p.9. apud NOVELINO, Marcelo. Ob.cit. p.487.
Decerto, daí a razão de o $\operatorname{art.} 7^{\circ}, \mathrm{XX}, \mathrm{CRFB}$ professar a proteção do mercado da mulher, mediante incentivos como o estímulo a sua contratação, a não discriminação de sexo para o exercício de atividades e a igual remuneração.

De igual modo, quiçá pelo efeito prisma da Constituição (oriunda da filtragem constitucional / contaminação virótica da Constituição) complementada por tais ações afirmativas, eclodiram no ordenamento jurídico pátrio diversas legislações com o desiderato (mens legis) de tutela às mulheres.

À guisa de exemplos, perlustra-se: a) a L.9029, de 13 de abril de 1995, que proíbe a exigência de atestados de gravidez, esterilização, e outras práticas discriminatórias para efeitos admissionais ou de permanência da relação jurídica de trabalho; b) a L.9504, de 30 de setembro de 1997, que dispõe que cada partido ou coligação preencherá o mínimo de $30 \%$ e o máximo de $70 \%$ para candidaturas de cada sexo (art.10, $3^{\circ}$ ); c) a L.11340, de 7 de agosto de 2006 (Lei Maria da Penha ${ }^{58}$ ), que trouxe mecanismos para coibir a violência doméstica e familiar contra a mulher, pois, não raras vezes, por ser mais fraca fisicamente, sofre abusos físicos e psicológicos.

c) Em favor de pessoas com deficiência.

A jurisprudência e a doutrina, vez ou outra, têm adotado diversas tipologias para se referir a pessoas em condições deficitárias (v.g. pessoa portadora de deficiência, pessoa com necessidades ou direitos especiais, pessoa com deficiência, etc). Neste ponto, importante destacar que mais relevante do que a terminologia a ser adotada é a real percepção de deficiência, de estar faltando algo.

Como adverte Hugo Nigro Mazzilli, $10 \%$ da população do mundo têm algum tipo de deficiência ${ }^{59}$. Nesse passo, ao invés de "meras

58. Nome da Lei dada para homenagear Maria da Penha Maia Fernandes, que, em 1983, foi vitimada (por duas vezes) pelo seu então marido Marco Antonio Heredia Viveros. Em razão das lesões por ela sofridas, no ambiente mais inesperado de todos (seu próprio lar) e oriunda de tiros disparados por seu próprio esposo enquanto ela dormia, Maria da Penha veio a ficar paraplégica, presa a uma cadeira de rodas.

59. Pela Organização Mundial de Saúde - OMS, só no campo da deficiência física, estima-se que haja meio bilhão de pessoas em todo o mundo (http:www.un.org/french/esa/social/disabled/). No Censo brasileiro de 2000, que apresenta outra metodologia e outros critérios para definição de deficiência, apontou-se que cerca de 24,5 milhões de pessoas tem algum tipo de incapacidade - o equivalente a 14,5\% da população do País (O Estado de São Paulo, 9 de maio de 2002, p.C-9). 
alterações de nomenclatura, que muitas vezes fazem mudanças fáceis, mas mascaram problemas", devemos mesmo é "combater firmemente a discriminação com ações concretas, não apenas recorrer a eufemismos" ${ }^{60}$.

Até porque, de Esparta (onde bebês deficientes eram sacrificados, lançados de precipícios - apothei) para os dias contemporâneos, as deformações congênitas, amputações traumáticas e as debilidades físicas, sensoriais ou cognitivas (permanentes ou transitórias) muitas vezes não encontram o amparo necessário da sociedade, que, pelo contrário as discriminam ora de forma clara, ora de forma dissimulada - por intermédio de piadas depreciativas e ditos mordazes.

Em verdade, ao que parece, muito dessa discriminação se perfaz pelo fato de os cidadãos se esquecerem que a subnutrição, os acidentes de trânsito ou do trabalho, o uso de drogas, a falta de uma política pré-natal ou sanitária adequada, estão entre as principais causas para o surgimento de debilidades intelectuais, motoras, sensoriais, funcionais, orgânicas, sociais ou de personalidade.

De qualquer maneira, nesse esteio, emergem ações públicas para uma maior guarida aos deficientes, seja no cerne constitucional (v.g. art.37, VIII, CRFB, que assegura percentual dos cargos e empregos públicos para pessoas portadoras de deficiência) ou no âmbito legal - este, permeado de exemplos: a) a L.7853, de 24 de outubro de 1989, que disciplinou a proteção das pessoas portadoras de deficiência e sua integração social, bem como de sua defesa sob o aspecto transindividual; b) a L.8213, de 24 de julho de 1991, que assegurou aos deficientes, desde que habilitados, de 2 a $5 \%$ das vagas para trabalho nas empresas com mais de 100 empregados; c) a L.8742, de 7 de dezembro de 1993, que reconheceu o benefício de prestação continuada em favor de pessoa portadora de deficiência que comprove não possuir meio de prover a própria manutenção e não tê-la provida pela família; d) a L.8899, de 29 de junho de 1994, que concede passe livre às pessoas portadoras de deficiência no sistema de transporte coletivo interestadual; e) a L.10048, de 8 de novembro de 2000 , que dá atendimento

60. MAZZILLI, Hugo Nigro. A defesa dos interesses difusos em juízo. São Paulo: Saraiva, 2011. p.685. prioritário às pessoas portadoras de deficiência física, entre outras, bem como impôs requisitos de acessibilidade em seu favor; etc.

\subsubsection{Mandado constitucional de criminalização}

Como pontuado, para que haja uma isonomia concreta, fática, se faz imperioso lançar mão de duas estratégias interdependentes (complementares): a) promocional, que visa propulsionar o avanço do direito a igualdade; e b) repressiva / punitiva, cujo objetivo é proibir, punir e, assim, eliminar as diferenças.

Deste modo, passada as ações afirmativas (que apresentam percepção promocional), é imprescindível analisarmos os denominados mandados constitucionais de criminalização (que detêm idiossincrasia repressiva).

Antolha-se! 0 poder constituinte originário, ao elaborar nossa bíblia política, esquadrinhou o que havia de essencial para a nação e o exteriorizou no corpo da Constituição. Ocorre que, tamanha a quantidade de matérias relevantes, nossa Magna Carta se tornou extensa (analítica /prolixa), de modo a não poder verticalizar grande parte do conteúdo nela tratado - encargo, este, que restou a ser regulamentado pela lei infraconstitucional ${ }^{61}$.

É, neste ponto, que emergem os mandados constitucionais de criminalização, onde, para a proteção de determinados valores jurídicos imprescindíveis, a constituição traça a obrigatoriedade de o Poder Legiferante vir a atuar com a criação de normas aptas à tutela de certos bens / interesses e a incriminação de condutas tendentes a vilipendia-los.

Isso porque, diante da importância de certas matérias, o poder constituinte originário (por bem) achou melhor externar aquilo que, em seu texto, possuía dignidade penal e deveria receber a tutela do Estado - frente a possibilidade (e porque não, risco) de o Poder Legislativo não abordá-las com devido cuidado.

61. De passagem, esta é a morada dos conceitos estudados sobre eficácia das normas constitucionais, onde se consagram: as de eficácia plena, limitada / relativa complementável, contida / redutível / restringível (José Afonso da Silva); absoluta / supereficazes (Maria Helena Diniz); de eficácia exaurida / esvaída (Carlos Ayres Britto); autoexecutáveis / bastantes em si, não autoexecutáveis (Rui Barbosa e Thomas Cooley). 
Desta sorte, nascem os mandados constitucionais, que podem ser:

a) expressos, onde fica clara a necessidade de se criminalizar determinada conduta. v.g. art.5 ${ }^{\circ}$ CRFB: a) XLI, a lei punirá qualquer discriminação atentatória dos direitos e liberdades fundamentais (v.Dec.5397/05); b) XLII, a prática do racismo constitui crime inafiançável e imprescritível, sujeita a pena de reclusão nos termos da Lei (v.L.7716/89); c) XLIII, a lei considerará crimes inafiançáveis e insuscetíveis de graça ou anistia a prática da tortura, o tráfico ilícito de entorpecentes e drogas afins, o terrorismo e os definidos como crimes hediondos, por eles respondendo os mandantes, os executores e os que, podendo evita-los, se omitirem (v.L8072/90, L9455/97, L11343/06); d) XLIV, constitui crime inafiançável e imprescritível a ação de grupos armados, civis ou militares, contra a ordem constitucional e o Estado Democrático (v.L7170/83); etc.

b) implícitos, onde a ordem de criminalização se mostra velada. v.g art. $5^{\circ}$ CRFB: a) caput, todos são iguais perante a lei, sem distinção de qualquer natureza, garantindo-se aos brasileiros e aos estrangeiros residentes no país a inviolabilidade do direito à vida, à liberdade, à igualdade, à segurança e à propriedade, nos seguintes termos (nesse passo, ilustra-se com os arts. 121/128 do CP, que trazem os crimes contra a vida); b) VI, é inviolável a liberdade de consciência e de crença, sendo assegurado o livre exercício dos cultos religiosos e garantida, na forma da lei, a proteção aos locais de culto e suas liturgias (v.Título $\mathrm{V}$ do Código Penal Brasileiro); c) $\mathrm{X}$, são invioláveis a intimidade, a vida privada, a honra e a imagem das pessoas, assegurado o direito a indenização pelo dano material ou moral decorrente de sua violação (v.Arts.138/145 CP); d) XXII, é garantido o direito a propriedade (v.Título II CP); etc.

Decerto, uma vez presente a promoção do bem de todos, sem preconceitos de origem, raça, sexo, cor, idade e quaisquer outras formas de discriminação como um dos objetivos fundamentais da República Federativa do Brasil (art. $3^{\circ}$, IV, CRFB), surge como mandado constitucional de criminalização a L.7716, de 5 de janeiro de 1989, que definiu os crimes resultantes de preconceito de raça ou de cor, etnia, religião ou procedência nacional.
No mesmo diapasão, apresenta-se o art.140,§3 do CP, que tipifica como crime a injúria preconceituosa - que verbera mais austeridade no seu tratamento jurídico-penal em relação à injuria simples ${ }^{62}$. Tal modalidade específica da injúria pune aquele que ofende a dignidade ou decoro da vítima com o emprego de referências a raça, cor, etnia, religião ou a condição de pessoa idosa ou portadora de deficiência.

De qualquer forma, é digno de nota que a presente qualificadora da injúria não se confunde com o delito de racismo, trazido pela L.7716, de 5 de janeiro de 1989.

Isso porque, além das consequências práticas (crime imprescritível, inafiançável e perseguida mediante ação penal pública incondicionada), o racismo ${ }^{63}$ traduz uma espécie de segregação (de pôr à margem da sociedade) em função da raça, cor, etnia, religião ou procedência nacional. Enquanto, de outro turno, a injúria preconceituosa (que é prescritível, afiançável e perseguida por ação penal pública condicionada à representação da vítima) é praticada por intermédio de xingamentos envolvendo a raça, cor, etnia religião ou origem da vítima.

62. Como adverte Fernando de Almeida Pedroso, a sanção aqui imposta é equiparável a prevista para muitos crimes contra a vida (auto-aborto - art.124 CP, homicídio culposo do Código Penal - art.121, $\left.\S 3^{\circ}\right)$ e para uma lesão corporal de natureza grave (art.129, $\left.\$ 1^{\circ} \mathrm{CP}\right)$. Deste modo, para não fazer "germinar ou vicejar uma injustiça a injúria discriminatória deve ser apreciada cum grano salis na sua identificação com o respectivo figurino típico, instando sejam introduzidas estreitas limitações à sua configuração jurídica. Não será suficiente ao aperfeiçoamento da injúria qualificada pelo preconceito, destarte, que alguém ultraje outrem pejorativamente chamando-o de negro, baiano, judeu, macaco, africano, carcamano, etc., fato que simplesmente trará a descortino a injúria na sua modalidade simples. Sempre será necessário agregar-se ao simples dolo de ofender a incolumidade moral alheia o elemento subjetivo do injusto, a conferir-lhe maior amplitude e contundência, consistente numa manifestação do sentimento de revelar, de forma prevalecente, a intenção de ferir não apenas a pessoa particularmente considerada e propriamente dita, mas de discriminá-la pela sua raça, etnia, religião, etc" (PEDROSO, Fernando de Almeida. Direito Penal: parte especial. São Paulo: Método, 2008. pp.424-425).

63. Em relação ao alcance da expressão racismo, é imperioso destacar a decisão do STF acerca do HC82424/RS, que debatia o direito da liberdade de expressão v. a tipificação do art.20, da L.7716/89 - em face da obra Holocausto: Judeu ou Alemão? (CASTAN, S.E. Porto Alegre: Revisão, 1988). A Suprema Corte, ante a tal questionamento, deliberou que racismo, antes de tudo, "é uma realidade social e política, sem nenhuma referência à raça enquanto caracterização física ou biológica, refletindo, na verdade, reprovável comportamento que decorre da convicção de que há hierarquia entre os grupos humanos, suficiente para justificar atos de segregação, inferiorização e até de eliminação de pessoas". 
Numa exemplificação clara e simples, Rogério Sanches Cunha ilustra a seguinte situação: xingar alguém fazendo referências à sua cor é injúria racial (v.g. caso do jogador Grafite, que em uma partida de futebol da Copa Libertadores da América, em 13 de abril de 2005, foi xingado de macaco por Leandro Desábato); por outro lado, impedir alguém de ingressar numa festa por causa da sua cor é racismo ${ }^{64}$.

Outrossim, é fruto de mandado constitucional de criminalização, sob o pálio da promoção do bem de todos, sem preconceitos de origem, raça, sexo, cor, idade e quaisquer outras formas de discriminação (um dos objetivos fundamentais da República Federativa do Brasil - art.3, IV, CRFB), a recente L.12984, de 2 de junho de 2014, que define como crime a discriminação dos portadores do vírus da imunodeficiência humana $^{65}$ (HIV) e doentes de aids ${ }^{66}$ - dentre tantos outros exemplos possíveis.

\subsection{A efetivação da igualdade no plano internacional}

De maneira inicial, é inconfutável que o direito à isonomia, por ser inerente aos homens, foi reconhecido (de acordo com o local de sua previsão) como direito fundamental, se inserido nas Constituições dos Estados; ou como direito humano, quando previsto em tratados internacionais.

Apesar desta distinção tipológica, é digno de nota que, seja no âmbito interno ou na esfera do Droit des gens (Law of Nations / Volkerrech), há uma intensa luta para se proteger denotado direito.

Até porque, os direitos humanos (dentre eles o direito à igualdade) refletem um construído axiológico, a partir de um espaço simbólico de luta e ação social ${ }^{67}$. 64. CUNHA, Rogério Sanches. Direito Penal: parte especial. 3a.ed.
São Paulo: Revista dos Tribunais, 2010. p.96.

65. Qualquer pessoa infectada pelo vírus e que na grande maioria das vezes está totalmente saudável.

66. Fase da infecção, de onde surgem inúmeras doenças oportunistas geradas pela deficiência do sistema imunológico do doente, resultado da ação do vírus.

67. PIOVESAN, Flávia. "Proteção dos direitos sociais: desafios do sistema global, regional e sul-americano". In: CORREIA, Fernando Alves; MACHADO, Jônatas E.M; LOUREIRO, João Carlos. (coord.). Estudos em homenagem ao Prof. Doutor José Joaquim Gomes Canotilho. Coimbra: Coimbra, 2012, 3.v. p743.
Traduzem processos que abrem e consolidam a busca pela dignidade humana ${ }^{68}$. São, decerto, "um dado construído, uma invenção humana, em constante processo de construção e reconstrução"69, que simbolizam a lei do mais débil (fraco) contra a lei do mais forte, "na expressão de um contrapoder em face dos absolutismos, advenham do Estado, do setor privado ou mesmo da esfera doméstica"70.

Daí, a morada de sua finalidade: como paradigma e referencial ético a orientar a ordem internacional.

Aliado a este fito (de modo que não retomemos a barbárie do totalitarismo, como o Nazismo, que negou o valor pessoa humana como fonte do Direito), surge a ideia de que a proteção dos direitos humanos não deve se reduzir ao domínio reservado do Estado, haja vista o fato deste tema revelar verdadeiro (e legítimo) interesse internacional.

Id est, passa-se a ter o ser humano como o fim do direito (não mais o meio). Flexibilizase o conceito de soberania nacional (indo da concepção de Hobbes - soberania centrada no Estado - para a de Kant - centrada na cidadania universal), de modo que os direitos humanos transcendem as fronteiras dos Estados, dada a valorização das pessoas humanas como novo interesse global.

Nessa vereda, empós a Declaração Universal dos Direitos Humanos (de 10 de dezembro de 1948), delineada pela Carta das Nações Unidas, criam-se diversosinstrumentos internacionais de proteção a estes direitos. Forma-se, sobretudo em razão da consciência ética compartilhada entre os Estados contemporâneos, um sistema (integrado por tratados internacionais) voltado a salvaguarda de direitos mínimos aos seres humanos ${ }^{71}$ (mínimo ético irredutível).

68. FLORES, Joaquín Herrera. Direitos humanos, interculturalidade e racionalidade de resistência. Mimeo. p.7 apud PIOVESAN, Flávia. "Proteção dos direitos sociais: desafios do sistema global, regional e sul-americano". Ob.cit. p.743.

69. ARENDT, Hannah. As origens do totalitarismo. Trad. Roberto Raposo, Rio de Janeiro, 1979. A respeito, ver também: LAFER, Celso. A reconstrução dos direitos humanos: um diálogo com o pensamento de Hannah Arendt. São Paulo: Cia das Letras, 1988. p.134. apud. Idem. p.744.

70. FERRAJOLI, Luigi. Diritti fondamentali - um dibattito teórico, a cura di Ermanno Vitale. Roma/Bari: Laterza, 2002. p.338. apud. Idem ibidem.

71. MAZZUOLI, Valério de Oliveira. Direito internacional público: parte geral. 7ạ.ed. São Paulo: Revista dos Tribunais, 2013. p.186. 
Para uma maior tutela, conjuntamente com o sistema normativo global, emergem sistemas regionais de proteção (particularmente na Europa, América e África ${ }^{72}$ ) que colimam internacionalizar os direitos humanos nos planos regionais. Nesta perspectiva, sob o axio da Declaração Universal, tais sistemas interagem em benefício dos indivíduos protegidos. Diga-se de passagem, se complementam inclusive com o sistema nacional de proteção, proporcionando a maior efetividade possível na tutela e promoção de direitos fundamentais.

Nesse ponto, vislumbra-se que o direito existe para proteger a pessoa humana (v. princípio do pro omine), não devendo haver restrições formais entre o direito nacional e o direito das gentes, de modo que sempre se aplique ao ser humano a norma que a ele lhe seja mais protetiva (vasos comunicantes / cláusulas de retroalimentação, denominados, no direito interno, de diálogo das fontes / de complementaridade - com espeque em Erick Jaime).

É neste prisma, de igual modo ao já externado, que emergem no plano internacional as políticas promocionais (que propulsionam o avanço do direito a igualdade) e repressivas / punitivas (cujo objetivo é proibir, punir e, assim, eliminar as diferenças) para que se galgue uma igualdade fática.

Nesse sentido, a existência da: a) Convenção sobre a eliminação de todas as formas de discriminação racial (que, no art.1ํ. parágrafo $4^{\circ}$, prevê a possibilidade de discriminação positiva mediante a adoção de medidas especiais de proteção ou incentivo a grupos ou indivíduos, com o escopo de promover sua ascensão na sociedade até um nível de equiparação com os demais); bem como a b) Convenção sobre a eliminação de todas as formas de discriminação contra a mulher $^{73}$ (que traz a possibilidade de Estados concretizarem ações afirmativas temporárias, com o desiderato de acelerar o processo de igualização de status entre homens e mulheres) e a c) Convenção relativa aos direitos das pessoas com deficiência (único tratado internacional que foi recepcionado com status, material e formal, de norma constitucional em nosso ordenamento).

\section{CONSIDERAÇÕES DERRADEIRAS}

Em breve síntese, o direito à igualdade, que sempre esteve embutido dentro das mais diversas acepções de justiça - desde a antiguidade -, pugna pelo tratamento justo por intermédio de um regulador de diferenças.

Veda-se, nessa vertente, o emprego arbitrário de tratamentos iguais para aqueles que se encontram em situações manifestamente desiguais ou, ainda, diferenciações destituídas de justificação razoável, baseadas em critérios discriminatórios, preconceituosos ou injustificáveis.

De igual modo, proíbe-se a discriminação (sentido negativo do princípio da igualdade)

72. Há um incipiente sistema árabe e a proposta de um sistema regional asiático (v. Carta Asiática de Direitos Humanos, em 1997, sob a forma de uma declaração feita por expressivas $O N G$ 's).

73. Na órbita das Nações Unidas há, ainda, a Declaração de Pequim (1995) e, no âmbito da Organização dos Estados Americanos (OEA), existe a Convenção Interamericana para prevenir, punir e erradicar a violência contra a mulher (1994).

Desmiude! Para a convenção Interamericana, entende-se por violência contra a mulher qualquer ato ou conduta baseada no gênero, que cause morte, dano ou sofrimento físico, sexual ou psicológico à mulher - tanto na esfera pública quanto na esfera privada (art.1 ${ }^{\circ}$ ). Daí, destaca Erival da Silva Oliveira, "a discriminação contra mulher significa toda distinção, exclusão ou restrição baseada no sexo e que tenha por objeto ou resultado prejudicar ou anular o reconhecimento, gozo, exercício, pela mulher, independentemente de seu estado civil, com base na igualdade do homem e da mulher, dos direitos humanos e das liberdades fundamentais nos campos político, econômico, social, cultural e civil ou em qualquer outro campo." (OLIVEIRA, Erival da Silva. Direito constitucional: direitos humanos. $2^{-}$ ed. São Paulo: Revista dos Tribunais, 2011. p.71) Inexiste, em nosso ordenamento, dispositivo que pontue acerca da hierarquia de tratado internacional no Brasil. Nesse passo, com a EC 45/04 e a inclusão do $\$ 3^{\circ}$, art. 5 CRFB, competiu ao STF (RE $466343 / S P$ ) se posicionar sobre o assunto. E, assim o fazendo, o Min. Gilmar Mendes (e maioria do STF) deliberou no sentido de que tratados de Direitos Humanos tem hierarquia supralegal (podendo ter status constitucional) e os demais tratados comuns tem hierarquia de lei ordinária. Ocorre que, conforme adverte Valério Mazzuoli, esse luminar de status de lei ordinária aos tratados comuns é bastante criticado. Isso porque: a) o STF fez pouco caso com relação a responsabilidade do Estado Brasileiro, pois admite que um compromisso internacional perca vigência em virtude da edição de lei posterior que com ele conflite (ou seja, viabiliza que, sem denúncia, um tratado possa unilateralmente ser revogado por um Estado-parte); b) por demais, tal fato sinaliza uma má-fe no âmbito internacional, já que pela Teoria do ato próprio (venire contra factum proprium non valet), o Congresso Nacional, a a aprovar um tratado internacional, assume uma obrigação negativa de não legislar em sentido contrário as obrigacões assumidas. Deste modo, se o Congresso Nacional assim o fizer (legislar), estaria obrando em oposição a conduta que teve anteriormente. (v. MAZZUOLI, Valério Oliveira. Ob.cit. pp.91-100). Desta forma, a solução seria andar na esteira do art. $5^{\circ} \mathrm{CP}$ e art. $1^{\circ} \mathrm{CPP}$, concedendo, a tais tratados comuns, hierarquia supralegal (Note! Os de Direitos Humanos, independentemente de sua internalização por maioria qualificada, teriam status constitucional material; e, empós sua internalização, com aprovação congressual qualificada, teriam status constitucional material e formal). 
e fomenta-se a insurgência do Poder Público (Estado intervencionista / social) para, por intermédio de ações afirmativas (discriminações positivas), compensar, ou quiçá eliminar, as desigualdades de natureza social, cultural e econômica (acepção positiva do referido axioma).

Isso porque, embora traduza um dos pilares do Estado Democrático de Direito, sendo ademais um dos valores centrais da ordem jurídico-constitucional, há muito a ser feito para que galguemos a colimada igualdade concreta, uma vez que, como asseverou Martin Luther King, aprendemos a voar como pássaros, a nadar como peixes, mas não a conviver como irmãos.

\section{BIBLIOGRAFÍA}

- ALEXY, Robert. Teoria dos direitos fundamentais. São Paulo: Malheiros, 2008;

- ARISTÓTELES. Ética a Nicômaco. Os pensadores. São Paulo: Abril Cultural, 1979;

- BARBOSA, Rui. Oração aos moços. São Paulo: Martin Claret, 2003;

- BOBBIO, Norberto. Igualdade e Liberdade. Trad. Carlos Nelson Coutinho. 2a ${ }^{\text {a.ed. Rio de }}$ Janeiro: Ediouro;

- CANotillho, J.J. Gomes; MOREIRA, Vital. Constituição da República Portuguesa anotada - Arts. $1^{\circ}$ a $107 .^{\circ}$. 4 ${ }^{\text {a }}$.ed. Coimbra: Coimbra, 2007;

- CUNHA, Rogério Sanches. Direito Penal: parte especial. 3a ${ }^{\text {a }}$.ed. São Paulo: Revista dos Tribunais, 2010;

- DíEZ-PICAZO, Luís María. Sistema de derechos fundamentales. 2a ${ }^{a}$ ed. Madrid: Civitas, 2005;

- DOUGLAS, William. A propósito das cotas nos concursos públicos. Disponível

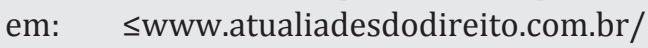
williamdouglas/2014/04/02/a-propositodas-cotas-nos-concursos-publicos $\geq$, Acesso em: 14 de junho de 2014;

- FERRAZ, Tércio Sampaio. Introdução ao Estudo do Direito. 3a edição. São Paulo: Editora Atlas, 2001. p.24;

- FERREIRA FILHO, Manoel Gonçalves. Curso de direito constitucional. 12a ed. São Paulo: Editora Saraiva, 1993;

- FRANCO, Francisco Manoel de Mello; HOUAISS, Antônio; VILLAR, Mauro de Salles. Minidicionário Houaiss da língua portuguesa. 2a edição. Rio de Janeiro: Objetiva, 2004;

- HOUAISS, Antônio; VILLAR, Mauro de Salles; FRANCO, Francisco Manoel de Mello. Minidicionário Houaiss da língua portuguesa. 2a edição. Rio de Janeiro: Objetiva, 2004;

- KELSEN, Hans. Teoria pura do direito. 5a edição. São Paulo: Editora Martins Fontes, 1996;

- LOPES, João Batista; MORAIS, Paulo Herber de. Da prova penal. Campinas: Julex Livros LTDA., 1978;

- MALUF, Sahid. Teoria geral do Estado. Revista e atualizada pelo Prof. Miguel Alfredo Malufe Neto. 26a.ed. São Paulo: Saraiva, 2003;

- MARINONI, Luiz Guilherme; MITIDIERO, Daniel; SARLET, Ingo Wolfgang. Curso de Direito Constitucional. 2ª ed. São Paulo: Revista dos Tribunais, 2013;

- Teoria geral do processo. 3a ed. rev. e atual. São Paulo: Revista dos Tribunais, 2008. v I;

- MARQUES, José Frederico. Estudos de direito processual penal. Rio de Janeiro: Forense, 1960;

- MAZZilli, Hugo Nigro. A defesa dos interesses difusos em juízo. São Paulo: Saraiva, 2011;

- MAZZUOLI, Valério de Oliveira. Direito internacional público: parte geral. 7ạ.ed. São Paulo: Revista dos Tribunais, 2013;

- MEDEIROS, Rui; MIRANDA, Jorge. 
Constituição portuguesa anotada. Coimbra: Coimbra, 2005. Vol.I.;

- MIRANDA, Jorge; MEDEIROS, Rui. Constituição portuguesa anotada. Coimbra: Coimbra, 2005. Vol.I.;

- MITIDIERO, Daniel; SARLET, Ingo Wolfgang; MARINONI, Luiz Guilherme. Curso de Direito Constitucional. 2a ${ }^{a}$.ed. São Paulo: Revista dos Tribunais, 2013;

- MORAIS, Paulo Herber de; LOPES, João Batista. Da prova penal. Campinas: Julex Livros LTDA., 1978;

- MOREIRA, Vital; CANOTILHO, J.J. Gomes. Constituição da República Portuguesa anotada - Arts. $1^{\circ}$ a $107 .{ }^{\circ} .4^{a}$.ed. Coimbra: Coimbra, 2007;

- NOVELINo, Marcelo. Manual de Direito Constitucional: volume único. $8^{a}$.ed. São Paulo: Método, 2013;

- OLIVEIRA, Erival da Silva. Direito constitucional: direitos humanos. $2^{a}$ ed. São Paulo: Revista dos Tribunais, 2011;

- PEDROSO, Fernando de Almeida. Direito Penal: parte especial. São Paulo: Método, 2008;

- PIOVESAN, Flávia. Ações afirmativas da perspectiva dos direitos humanos.
Cadernos de pesquisa. v.35, $\mathrm{n}^{\circ} .124$, jan/ abr.2005;

- —Proteção dos direitos sociais: desafios do sistema global, regional e sul-americano". In: CORREIA, Fernando Alves; MACHADO, Jônatas E.M; LOUREIRO, João Carlos. (coord.). Estudos em homenagem ao Prof. Doutor José Joaquim Gomes Canotilho. Coimbra: Coimbra, 2012, 3.v;

- SARLET, Ingo Wolfgang; MARINONI, Luiz Guilherme; MITIDIERO, Daniel. Curso de Direito Constitucional. 2 ${ }^{a}$.ed. São Paulo: Revista dos Tribunais, 2013;

- SCOTT, Joan. O enigma da igualdade. Estudos Feministas. Florianópolis, $n^{\circ} 13$ (1), jan./abr., 2005;

- TOURINHO FILHO, Fernando da Costa. Processo penal. 8 ${ }^{\text {a }}$ ed. São Paulo: Saraiva, 1986;

- VILLAR, Mauro de Salles; HOUAISS, Antônio; FRANCO, Francisco Manoel de Mello. Minidicionário Houaiss da língua portuguesa. $2^{\underline{a}}$ edição. Rio de Janeiro: Objetiva, 2004. 